\title{
Ф.Ф. Губайдуллин
}

\section{ЦИФРОВАЯ КОНВЕРТАЦИЯ АНАЛОГОВЫХ ЗАПИСЕЙ СЕЛЬКУПСКИХ ${ }^{1}$ ИНСТРУМЕНТАЛЬНЫХ НАИГРЫШЕЙ}

\begin{abstract}
В статье даётся краткая оценка программным продуктам, разработанным для платформы Windows. Это программы-конвертеры, нотные и аудиоредакторы. Основное место уделено конвертерам, позволяющим переводить (конвертировать) аудиозаписи из волнового формата (Wave) в цифровой (Midi). Это направление работы с традиционной музыкальной культурой пока ещё мало используется в учебном процессе. Тем не менее практика показывает, что согласованное сочетание компьютерных технологий с традиционным слуховым методом существенно улучшит работу с традииионной музыкальной культурой селькупов и имеет значительные перспективы в академической учебной сфере.

Ключевые слова: селькупы, инструментальные наирыци, расшифровка, конвертация.
\end{abstract}

Фольклорная экспедиция всегда была перспективным направлением изучения традиционной инструментальной культуры селькупского этноса. В процессе полевого поиска, как правило, ведётся фотографирование и запись: аудио, имеющая многолетнюю апробацию, и видео, сравнительно недавно появившаяся в арсенале фольклориста-исследователя. После экспедиционной работы весь материал систематизируется и далее расшифровывается согласно требованиям предмета «Расшифровка и аранжировка народных мелодий», входящего в федеральный компонент Государственного образовательного стандарта.

Расшифровка аудиозаписей - процесс сложный и длительный, требующий от исследователя тонкого слуха и опыта работы с аналоговыми записямиㄹ․ Для работы с ними ранее использовался специальный магнитофон, позволяющий делать остановку и многократное прослушивание необходимого фрагмента. Процесс этот всегда считался утомительным и требовал от «расшифровщика» значительного напряжения слуха для селекции полезного сигнала от шумового. Недавно появившиеся мультимедийные технологии значительно облегчили эту задачу, превратив трудоёмкий процесс в работу компьютерного оператора с инструментальными программными средствами по записи, созданию копий и редактированию [1. С. 9].

Из множества мультимедийных (цифровых) направлений задействованы в основном программные продукты, разработанные для платформы Windows $^{3}$. Это - конвертеры, нотные редакторы, аудиоредакторы и частично медиапроигрыватели и системные программные решения.

\footnotetext{
${ }^{1}$ Селькупы - один из небольших аборигенных этносов Сибири, проживающий на территории Ямало-Ненецкого автономного округа Тюменской области, в Красноярском крае и Томской области.

${ }^{2}$ Аналоговая запись представляет собой сигнал, записанный на магнитный носитель.

${ }^{3}$ Некоторые программные продукты могут использоваться и в других популярных платформах, таких как Linux, Macintosh.
} 
Подробный анализ компьютерных технологий, используемый в этноорганологии, самостоятельная тема, не входящая в приоритеты небольшой статьи, но для освещения заявленной темы ниже даётся их краткая характеристика.

Программы-конвертеры и нотные редакторы предлагают перевод (конвертацию) записей из волнового формата (Wave) в цифровой (Midi) и далее в нотный интерфейс. Это направление работы с традиционной музыкальной культурой пока ещё очень робко используется в учебной расшифровке, всегда проводимой слуховым методом.

Наиболее известные программные решения для конвертации аудиозаписей с последующей их нотацией приведены в таблице.

Наиболее распространённые программы-конвертеры и нотные редакторы

\begin{tabular}{|l|l|l|}
\hline \multicolumn{1}{|c|}{ Программа } & \multicolumn{1}{|c|}{ Платформа } & \multicolumn{1}{|c|}{ Краткая характеристика } \\
\hline Audio to midi & Windows & Конвертер Аидіо в MIDI формат \\
\hline AKoff Music Composer & Windows & $\begin{array}{l}\text { Распознаёт и преобразовывает } \\
\text { аудиозаписи в MIDI формат }\end{array}$ \\
\hline $\begin{array}{l}\text { Intelliscore Ensemble } \\
\text { Polyphonic WAV to MIDI } \\
\text { Converter }\end{array}$ & Windows & $\begin{array}{l}\text { Конвертер Audio в MIDI формат, } \\
\text { распознает инструменты в Audio } \\
\text { и создаёт МIDI дорожки для } \\
\text { каждого инструмента }\end{array}$ \\
\hline Notation Player & Windows & $\begin{array}{l}\text { Отображает форматы .mid, .kar, not } \\
\text { в графическом нотном интерфейсе } \\
\text { с возможностью воспроизведения } \\
\text { и печати }\end{array}$ \\
\hline Sibelius & Windows, Linux & Нотный редактор \\
\hline Finale & Windows, Macintosh & Нотный редактор и др. \\
\hline
\end{tabular}

Перевод аудиофайлов ${ }^{1}$ в midi и далее в нотный интерфейс при помощи перечисленных программ пока не даёт качественных результатов, так как при одних и тех же настройках они требуют слуховой правки. Это связано с отсутствием специализированных селекционных фильтров, которые не могут отделить полезный сигнал от помех. Даже в самую совершенную студийную запись неизбежно попадают посторонние сигналы (природный и техногенный шум, перемещение респондента и др.), поэтому селекция полезного и шумового сигнала пока невозможна без слухового метода.

Для работы с медиатехнологиями в условиях учебного процесса и обеспечения методологической поддержки имеется обширное количество методического материала [2-6 и др.]. Публикации же, касающиеся сугубо конвертации аудиозаписей, немногочисленны и представлены чаще всего узкоспециализированными описаниями компьютерных приложений с анализом их технологических аспектов [7, 10].

Одна из работ, представляющих интерес для фольклориста, выполнена композитором М.И. Карпец, где автор предлагает вместо привычных парти-

\footnotetext{
${ }^{1}$ Название «аудио» мы используем как общий термин, к которому относятся наиболее распространенные цифровые звукозаписи - mp3, wave, wma и т.д.
} 
тур с использованием нотного письма применять графический интерфейс. Он считает, что это «...позволит избежать терминологической путаницы и упростит практикам ориентацию в широком спектре современной многовариантной визуально-графической записи музыки» [8. С. 264].

Ниже мы рассмотрим это направление на примере расшифровки одной из наших записей. В качестве основных программных средств, направленных на воспроизведение музыкальных файлов и дальнейшее распознавание нот, рассмотрим такие, как WIDI Recognition System (далее - WIDI), celemony Melodyne (далее - Melodyne) и Transcribe.

WIDI - программа-конвертер, работающая по распространённому алгоритму действий, переводящая аудиофайл в midi и уже далее в любой нотный редактор, который поддерживает работу с midi файлами. Отличительной чертой программы являются удобные настройки.

Melodyne - программа предназначена для предварительного редактирования аудиозаписей и работает по новейшему алгоритму direct note access ${ }^{1}$. Данная технология позволяет из общего потока аудио выделить полезный сигнал, частично отсекая помехи, и преобразовывать их в графический интерфейс.

Transcribe - специализированная программа-плеер, которая позволяет проигрывать и закольцовывать отдельные участки аудиофайла, изменять темп без изменения тональности, что дает возможность более тщательно и детально расшифровывать аудиозапись. Алгоритм работы - спектральный анализ (сигналограмма) - позволяет определить по выбранному участку записи частоты входящих в него звуков и сразу сопоставить их с частотами тонов принятого музыкального строя, т.е. визуально определять высоту и длительность звука за счёт пиков спектра на графике.

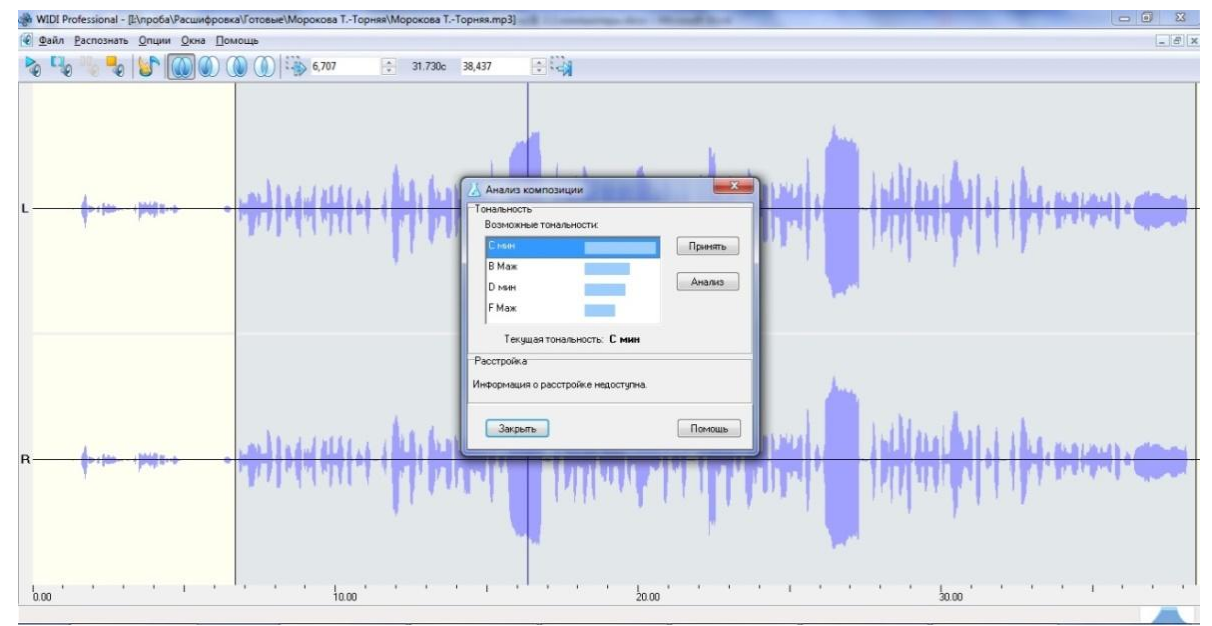

Pис. 1. Screenshot ${ }^{2}$ WIDI (WAVE-интерфейc), определение тональности записи «Торняя»

\footnotetext{
${ }^{1}$ Direct note access (DNA) (англ.) - прямой доступ к ноте, разработчик Celemony Software gmbH, автор идеи Peter Neubäcker (http://www.celemony. com).

2 screenshot (англ.) - снимок экрана.
} 
Программы WIDI и Melodyne автоматически определяют тональность в темперированном хроматическом формате. Transcribe же не требует определения тональности, что делает её более привлекательной, так как в фольклорных записях определить тональность даже с помощью программных средств довольно сложно, так как монодийная селькупская мелодика в ряде случаев не имеет тонального звукоряда и выраженного метроритма.

Рассмотрим работу программ на практике, взяв для примера селькупскую детскую песенку «Торняя» (сельк. Оленёнок) ${ }^{1}$ и выполним её конвертацию (аудиозапись не имеет серьёзных помех).

В аудиозаписи «Торняя» программы WIDI и Melodyne определяют тональность как c-moll. (рис. 1, 2).

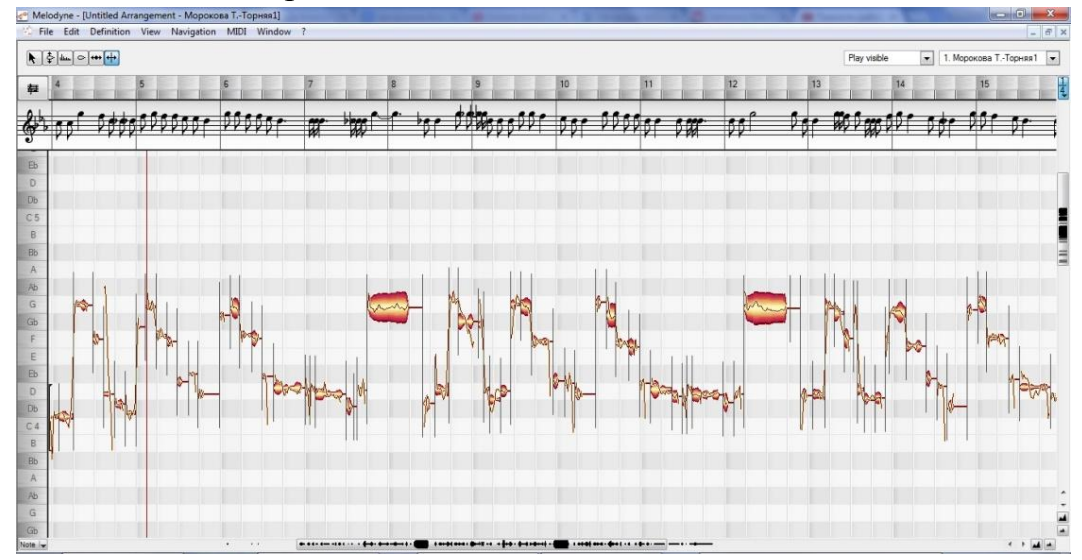

Рис. 2. Screenshot Спектральный (WAVE интерфейс) и нотный интерфейс программы Melodyne, определение тональности записи «Торняя»

Следующий шаг работы программы WIDI - конвертация сигнала в спектральный и нотный интерфейс (рис. 3).

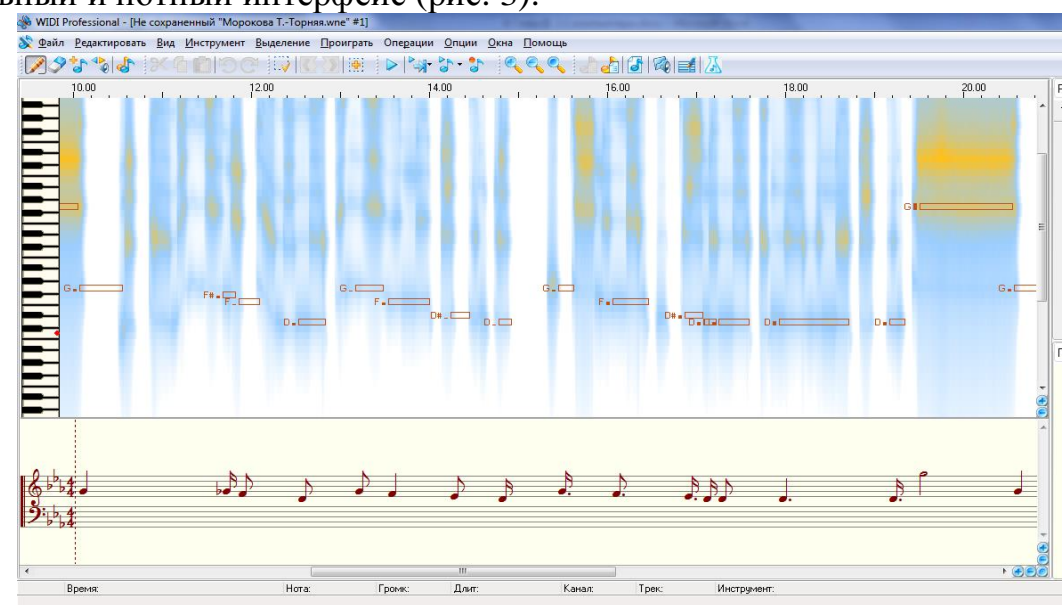

Рис. 3. Спектральный и нотный интерфейс «Торняя». Screenshot программы WIDI

\footnotetext{
${ }^{1}$ Напев Т.А. Мороковой, запись предоставлена И.В. Петровой.
} 
После небольшой слуховой правки аудиосигнал приобретает вид, удобный для музыковедческой обработки (нотный пример 1).

\section{Нотный пример 1}

Результат комбинированной расшифровки детской песенки «Торняя»:

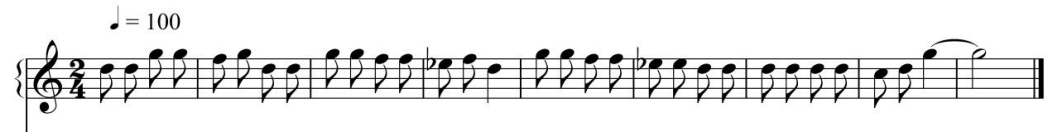

Несколько сложнее дело обстоит с расшифровкой наигрышей на селькупских сигнальных аэрофонах. Многие темброво-мелодические обороты часто невозможно обозначить знаками академической семиографии.

Рассмотрим это на примере расшифровки звукоподражательного сигнала в исполнении на манке «Сыча Тёкай» (сельк. «манок на гуся») [9. С. 18].

Сам инструмент представляет собой две скреплённые между собой гильзы от охотничьего ружья 16-го и 28-го калибра (По Хорнбостелю-Заксу относится к набору закупоренных флейт - разновидность флейты Пана, индекс 421.112.2).

Расшифровка с помощью программы Transcribe с последующей конвертацией в нотный текст показала следующий результат (нотный пример 2).

\section{Нотный пример 2}

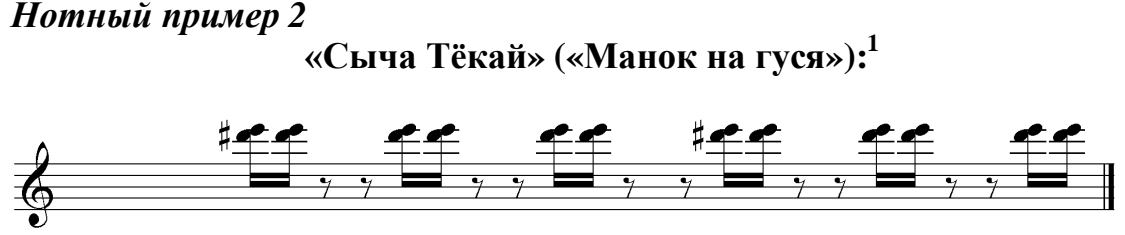

Аналогичным образом была проведена расшифровка игры на «Сыча чынқый» (сельк. «манок на лебедя»). По Хорнбостелю-Заксу инструмент классифицируется как сосудная флейта с щелью без боковых отверстий, индекс 421.221.41 [10. С. 39].

Расшифровка сигнала с применением программы Melodyne показала следующее (нотный пример 3).

\section{Нотный пример 3}

«Сыча чынқый» («Манок на лебедя»): ${ }^{2}$

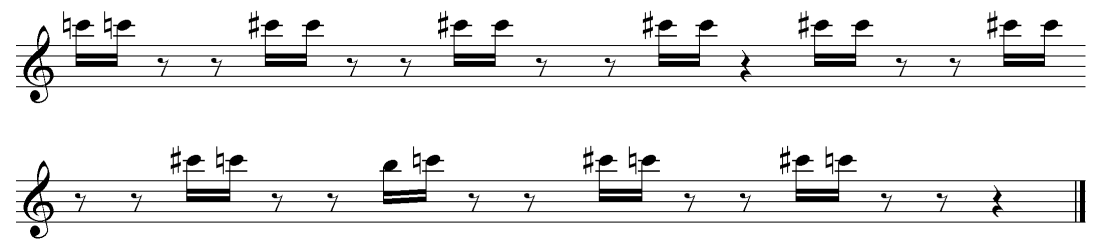

Благодаря цифровым технологиям появились новые возможности в преподавании таких дисциплин, как «Расшифровка и аранжировка народных мелодий» [11. С. 12], которая ранее велась исключительно слуховым мето-

\footnotetext{
${ }^{1}$ Информатор Владимир Каргачёв, на р. Каралька АНАО, июнь 2012 г. Звукозапись Ф.Ф. Губайдуллина.

${ }^{2}$ Там же.
} 
дом. Слуховая расшифровка и её запись средствами нотографики крайне условно отражала реальное звучание оригинала, но давала простор творческому воображению. Компьютерная же расшифровка точна, но представляет больше семантико-математический, чем созидательный интерес.

Опыт работы показывает, что наиболее приемлемыми для применения в учебной сфере являются Melodyne и Transcribe ${ }^{1}$. Благодаря этим программным средствам появляется возможность существенно расширить творческий процесс в музыкальном образовании.

Сочетание двух направлений расшифровки - слухового и цифрового - обогащает процесс работы с традиционной музыкальной культурой селькупов.

\section{Литература}

1. Докторова E.A. Мультимедиа технологии : конспект лекций. Ульяновск : УлГТУ, 2009. $39 \mathrm{c}$.

2. Карпеи И.М. Нотация в электронной и компьютерной музыке (проблемы терминологии) // Изв. Рос. гос. пед. ун-та им. А.И. Герцена. 2009. № 99. С. 262-266.

3. Гулк Е.Б. Современные подходы к формам организации процесса обучения в высшей школе // Научно-технические ведомости Санкт-Петербургского государственного политехнического университета : Гуманитарные и общественные науки. 2013. № 1 (167). С. 30-33.

4. Горбунова И.Б. Романенко Л.Ю. Родионов П.Д. Музыкально-компьютерные технологии в формировании информационной компетентности современного музыканта // Научнотехнические ведомости Санкт-Петербургского государственного политехнического университета. Гуманитарные и общественные науки. 2013. № 1 (167). С. 39-48

5. Гаврилова Л.Г. Феномен мультимедиа : технологический, культурологический и искусствоведческий взгляд // Традиции и инновации изучения проблем языка и культуры в новой образовательной парадигме. Всерос. науч.-метод. конф. (с международным участием),. Оренбург, 4-6 февраля 2015 г. Оренбург, 2015. Секция 13. С. 1776-1783.

6. Юнусова В.Н., Харуто А.В. Компьютерный анализ музыки народов мира. Методы и перспективы // Архаика - Авангард. СПб., 2013. С. 17-22.

7. Харуто А.В. Компьютерные методы анализа звука в музыковедческом исследовании // Музыка и время. 2005. № 8. С. 55-59.

8. Карпец И.М. Нотация в электронной и компьютерной музыке (проблемы терминологии) // Изв. Рос. гос. пед. ун-та им. А.И. Герцена. 2009. № 99. С. 262-266.

9. Губайдуллин Ф.Ф. Инструментальная культура селькупов (по материалам этнографической экспедиции) // Проблемы музыкальной науки. 2014. № 2 (15). С. 14-20.

10. Губайдуллин Ф.Ф. Журавлиная река : путевой дневник. Уфа : Изд-во БГПУ, 2013. 60 с.

11. Рахимов Р.Г. Музыкальная информатика : учеб. пособие. Уфа : Изд-во БГПУ, 2015. 48 с.

Gubaydullin Firgat F. Ufa State academy of arts of Z. Ismagilova (Krasnosel'kup, JaNAO, the Russian Federation).

E-mail: korablik78@gmail.com

DOI: $10.17223 / 22220836 / 21 / 11$

DIGITAL CONVERTING OF THE ANALOG RECORDING OF SELKUPSKY TOOL FOLK TUNES

Key words: Selkups, instruments folk tunes, decoding, converting.

Traditional instrument music of the small people of the Russian North even more often becomes object of studying and a source of inspiration of composers, arrangers and executors. In this connection requirements to quality of fixings and The notation national melodies and folk tunes have increased. If earlier quite satisfied the acoustical decodings executed «on memory» and «on hearing» the decodings executed even with application of audio and video of equipment now became a little comprehensible.

1 Данный вывод носит субъективный характер. Применение других медиапродуктов конвертации сигналов значительно дополнит и расширит творческий процесс, что в конечном итоге даст более глубокие результаты. 
In the average and higher specialized establishments which are engaged in music, a subject «Decoding and arrangement of national melodies» are included into a federal component of the State educational standard, and more and more a place in this subject occupy digital technologies.

The detailed analysis of computer technologies used in Ethnosorganology, the independent theme which is not entering into priorities of small article, but for illumination of the declared theme is given the short characteristic of software on platform Windows.

Folklore expedition always was a perspective direction of studying of traditional tool culture селькупского ethnos. In the course of field search photographing and record, as a rule, is conducted: the audio, having long-term approbation, and video which rather have recently appeared in an arsenal of the specialist in folklore-researcher.

In article the short estimation is given to the software products developed for platform Windows. These are programs converters, musical and audio editors. The basic place is given the converters, allowing to translate to (convert) audio of record from a wave format (Wave) in digital (Midi). This direction of work with traditional musical culture for the present is a little used in educational process.

On an example of the audio records executed by the author of article in the course of field search, the algorithm of converting of a Wave-signal in the musical interface is resulted. The conclusion becomes, that thanks to programs-converters there is a possibility essentially to expand creative sector of music education. Transfer of audiophiles in a midi-format and in the musical interface by means of converters yet does not give, further, final results and at the same options demand acoustical editing. Even extraneous signals inevitably get to the most perfect studio recording (natural and ethnogeny noise, moving of the respondent, etc.), therefore selection of a useful and noise signal while is impossible without an acoustical method.

Nevertheless, practice shows, that the co-ordinated combination of computer technologies to a traditional acoustical method will essentially improve work with traditional musical culture of Selkupand has considerable prospects in the academic educational sphere.

\section{References}

1. Doktorova, E.A. (2009) Mul'timedia tekhnologii: konspekt lektsiy [Multimedia Technology]. Ulyanovsk: UlGTU.

2. Karpets, I.M. (2009) Notatsiya v elektronnoy i komp'yuternoy muzyke (problemy terminologii) [The notation in the electronic and computer music (terminology problems)]. Izv. Ros. gos. ped. un-ta im. A.I. Gertsena - Izvestia: Herzen University Journal of Humanities \& Science. 99. pp. 262-266.

3. Gulk, E.B. (2013) Sovremennye podkhody k formam organizatsii protsessa obucheniya v vysshey shkole [Modern approaches to the forms of organization of educational process in high school]. Nauchnotekhnicheskie vedomosti Sankt-Peterburgskogo gosudarstvennogo politekhnicheskogo universiteta: Gumanitarnye i obshchestvennye nauki - St. Petersburg State Polytechnical University Journal. 1(167). pp. 30-33.

4. Gorbunova, I.B. Romanenko, L.Yu. \& Rodionov, P.D. (2013) Muzykal'no-komp'yuternye tekhnologii v formirovanii informatsionnoy kompetentnosti sovremennogo muzykanta [Music and computer technology in the formation of information competence of the modern musician]. Nauchno-tekhnicheskie vedomosti Sankt-Peterburgskogo gosudarstvennogo politekhnicheskogo universiteta: Gumanitarnye i obshchestvennye nauki - St. Petersburg State Polytechnical University Journal. 1(167). pp. 39-48

5. Gavrilova, L.G. (2015) [Media Phenomenon: technological, cultural and artistic view]. Traditsii $i$ innovatsii izucheniya problem yazyka $i$ kul'tury v novoy obrazovatel'noy paradigm [Tradition and innovation of language learning and cultural issues in the new educational paradigm]. The All-Russian Research Conference with International Participation. Orenburg. 4 to 6 February 2015. Orenburg: Orenburg State University. pp. 1776-1783. (In Russian).

6. Yunusova, V.N. \& Kharuto, A.V. (2013) Komp'yuternyy analiz muzyki narodov mira. Metody i perspektivy [Computer analysis of the music of the world. Methods and prospects]. Arkhaika - Avangard. [Archaic - Vanguard]. Proc. of the International Symposium. St. Petersburg. 2 to 5 December 2013. pp. 17-22.

7. Kharuto, A.V. (2005) Komp'yuternye metody analiza zvuka v muzykovedcheskom issledovanii [Computer methods of sound analysis in musicological research]. Muzyka $i$ vremya-Music and Time. 8. pp. 55-59.

8. Gubaydullin, F.F. (2014) The Instrumental Musical Culture of the Selkups (Based on the Materials of an Ethnographical Expedition). Problemy muzykal'noy nauki - Music Scholarship. 2(15). pp. 14-20. BSPU.

9. Gubaydullin, F.F. (2013) Zhuravlinaya reka: putevoy dnevnik [The Crane River: A travel diary]. Ufa:

10. Rakhimov, R.G. (2015) Muzykal'naya informatika [Musical Informatics]. Ufa: BSPU. 